(c) American Dairy Science Association, 2006.

\title{
Dry Matter Intake and Blood Parameters of Nonlactating Holstein and Jersey Cows in Late Gestation
}

\author{
P. D. French \\ Department of Animal Sciences, Oregon State University, 112 Withycombe Hall, Corvallis 97331
}

\begin{abstract}
An experiment was conducted using 14 multiparous Holstein and 14 multiparous Jersey cows to determine if dry matter intake (DMI), specifically the decline in prepartum DMI and plasma parameters differed between breeds. Cows were blocked by expected calving date and received a dry cow total mixed ration (15\% crude protein and 39\% neutral detergent fiber) beginning $30 \mathrm{~d}$ before expected calving date. At calving, cows were switched to a lactation total mixed ration (17\% crude protein and $33 \%$ neutral detergent fiber). Data were collected from d 23 prepartum to $\mathrm{d} 1$ postpartum. Body weight was greater for Holsteins compared with Jerseys, but body condition score did not differ between breeds. Dry matter intake decreased for both Holsteins and Jerseys as parturition approached. The interaction of breed $\times$ day prepartum was significant for DMI with the magnitude of depression being greater for Holsteins compared with Jerseys. Plasma glucose and $\beta$-hydroxybutyrate was similar between breeds. Plasma nonesterified fatty acids (NEFA) were similar for the two breeds up to $\mathrm{d} 5$ prepartum, but greater for Holsteins compared with Jerseys thereafter. The decline in prepartum DMI was positively correlated to plasma NEFA for Holsteins, but not for Jerseys. These results indicate that breed differences exist for the decline in prepartum DMI and plasma NEFA. In addition, these data show an association between prepartum DMI depression and plasma NEFA but do not suggest a causal relationship.

Key words: dairy breed, prepartum, dry matter intake
\end{abstract}

\section{INTRODUCTION}

The transition from late gestation to early lactation is a critical phase in the production cycle of dairy cows. Notably, the prepartum period is characterized by declining DMI and elevated plasma NEFA (Grummer, 1995). Voluntary DMI of multiparous Holstein cows decreases approximately $32 \%$ from $21 \mathrm{~d}$ prepartum to

Received May 5, 2005.

Accepted October 24, 2005.

E-mail: Patrick.French@oregonstate.edu
$1 \mathrm{~d}$ prepartum with the greatest decline occurring during the last week of gestation (Hayirli et al., 2003). Grummer (1995) reported positive correlations between prepartum DMI and postpartum DMI. Therefore, recommendations have given priority to maximizing DMI of the prefresh cow (Grummer, 1995; Grummer et al., 2004).

Numerous factors have been implicated with prepartum DMI depression, including plasma NEFA. Grummer (1995) reported significant negative correlations between DMI at $1 \mathrm{~d}$ prepartum and plasma NEFA. The coinciding decrease in DMI and increase in circulating concentrations of plasma NEFA the week before calving indicates an associative relationship.

A considerable amount of literature is available describing changes in voluntary DMI of Holsteins during the prepartum period (Hayirli et al., 2002, 2003). However, information regarding voluntary DMI of Jersey cows compared with Holsteins is lacking. Importantly, Rastani et al. (2001) reported that Holsteins had greater plasma NEFA concentration 1 wk postpartum compared with Jerseys. Plasma NEFA at 2 wk prepartum was similar for Holstein and Jersey cows (Rastani et al., 2001), but this is before the precipitous rise in plasma NEFA concentration that occurs 1 wk prepartum through calving. However, it is not known whether prepartum DMI, magnitude of prepartum DMI depression, and plasma NEFA immediately before calving differs between breeds. If plasma NEFA at 1 wk postpartum is indicative of prepartum NEFA, then plasma NEFA of Jerseys cows around the time of calving may be lower than that of Holsteins and the magnitude of prepartum DMI depression may be less for Jersey cows.

Additional information is needed regarding the nutritional management of Jersey cows in late gestation. Therefore, the objective of this study was to determine whether breed differences in prepartum voluntary DMI and tissue mobilization exist between Jerseys and Holsteins in late gestation.

\section{MATERIALS AND METHODS}

The Oregon State University Animal Care and Use Committee approved all procedures involving animals. Fourteen multiparous Holsteins and 14 multiparous 
Jerseys were blocked according to expected calving date approximately $30 \mathrm{~d}$ before parturition. Cows were housed in freestalls and individual daily intake was maintained by Calan gates (American Calan, Northwood, $\mathrm{NH}$ ). After a 7-d adjustment period to Calan gates, DMI was measured from $23 \mathrm{~d}$ prepartum to $1 \mathrm{~d}$ postpartum. Cows were fed for ad libitum intake and orts maintained at approximately $10 \%$. Cows were moved to individual maternity pens when parturition was imminent based on physical signs and remained there until $1 \mathrm{~d}$ postpartum.

Cows received a TMR once daily at $0700 \mathrm{~h}$. The composition (DM basis) of the prepartum diet was $34.9 \%$ corn silage, $21.2 \%$ oat hay, $15.9 \%$ alfalfa hay, $18.3 \%$ ground corn, $7.0 \%$ soybean meal, and $2.7 \%$ mineralvitamin premix. The prepartum diet contained (DM basis) $15 \% \mathrm{CP}, 39 \% \mathrm{NDF}, 38 \% \mathrm{NFC}, 3 \%$ ether extract, $5 \%$ ash, and $1.51 \mathrm{Mcal}$ of $\mathrm{NE}_{\mathrm{L}} / \mathrm{kg}$. At parturition, cows were switched to a diet that contained $22.5 \%$ corn silage, $25.1 \%$ alfalfa hay, $5.8 \%$ grass silage, $13.1 \%$ rolled corn, $13.1 \%$ rolled barley, $10.3 \%$ whole cottonseed, $5.0 \%$ soybean meal, $3.6 \%$ corn distillers grain, and $1.5 \%$ mineral-vitamin premix. The postpartum diet contained (DM basis) $17 \% \mathrm{CP}, 33 \% \mathrm{NDF}, 38 \% \mathrm{NFC}, 5 \%$ ether extract, and $7 \%$ ash. Ingredient DM was determined weekly by drying at $60^{\circ} \mathrm{C}$ for $48 \mathrm{~h}$ in a forced-air oven and diets were adjusted accordingly to maintain desired ingredient composition. Ingredients were sampled weekly and monthly composites analyzed for CP (AOAC, 1997) and NDF (Van Soest et al., 1991), ether extract (AOAC, 1997), and ash (AOAC, 1997). Neutral detergent fiber was measured using the Ankom A200 (Ankom Technology Corp., Fairport, NY) filter bag technique. Nonfiber carbohydrate was calculated as NFC = 100 - CP - NDF - ether extract - ash, where NDF was not corrected for $\mathrm{N}$. The energy value of the diet was calculated according to NRC (2001) at $2 \times$ maintenance intake. Book values were used for neutral detergent insoluble $\mathrm{N}$ and lignin.

Blood samples were collected via venipuncture of the jugular using EDTA and heparinized Vacutainer tubes (Becton Dickinson, Franklin Lakes, NJ). Samples were obtained on d 21 and 14 prepartum, then every other day until $7 \mathrm{~d}$ prepartum, and daily thereafter until parturition. In addition, samples were collected within $4 \mathrm{~h}$ after calving and again at $24 \mathrm{~h}$. Blood samples were centrifuged at $1,600 \times \mathrm{g}$ for $15 \mathrm{~min}$ and frozen at $-20^{\circ} \mathrm{C}$ until analysis. Plasma collected from EDTA containing tubes was analyzed for NEFA (Johnson and Peters, 1993; NEFA-C kit; Wako Chemicals USA, Richmond, VA), whereas plasma from heparin containing tubes was analyzed for BHBA (Williamson and Mellanby, 1974; Sigma procedure \#310; St. Louis, MO) and glucose (Raabo and Terkildsen, 1960; Sigma procedure \#510).
Body weight and BCS were measured weekly. Two individuals independently assigned BCS to cows ( 1 = thin, 5 = fat; Wildman et al., 1982). Net energy intake was determined by multiplying daily DMI by the calculated energy value of the diet. Energy required for maintenance and pregnancy was computed using NRC (2001). Animals were assumed to have reached mature BW and calf birth weight used was $43 \mathrm{~kg}$ for Holsteins and $25 \mathrm{~kg}$ for Jerseys. Estimated energy balance prepartum was calculated on a daily basis as energy balance $=$ net energy intake - (net energy for maintenance + net energy for pregnancy).

\section{Statistical Analyses}

Data were analyzed as repeated measures using the MIXED procedure of SAS (SAS Institute, 1999) for ANOVA with cow within block by breed as a random effect and breed (Holstein or Jersey) as a fixed effect in a complete block design. In addition, the model included all interactions. Autoregressive covariate structure was used for equally spaced repeated measures (DMI, BW, and BCS) and spatial power law for the unequally spaced plasma metabolites (Littell et al., 1996). Differences were considered significant at $P<0.05$. The model was:

$$
\mathrm{Y}_{\mathrm{ijklm}}=\mu+\rho_{\mathrm{i}}+\alpha_{\mathrm{j}}+\mathrm{c}_{(\mathrm{ij}) \mathrm{k}}+\gamma_{\mathrm{l}}+\alpha \gamma_{\mathrm{il}}+\varepsilon_{\mathrm{ijklm}}
$$

where $\mathrm{Y}_{\mathrm{ijk} l \mathrm{~m}}=$ the dependent variable in block $\mathrm{i}$ and breed $\mathrm{j}$ for cow $\mathrm{k}$ at day or wk $\mathrm{l} ; \mu=$ common mean; $\rho_{\mathrm{i}}=$ effect of block i $(i=1,2, \ldots 14) ; \alpha_{j}=\operatorname{effect}$ of breed $\mathrm{j}(\mathrm{j}=$ Holstein or Jersey); $\mathrm{C}_{(\mathrm{ij}) \mathrm{k}}=$ random effect of cow $\mathrm{k}(\mathrm{k}=$ $1,2, \ldots 14)$ within block $\mathrm{i}$ and breed $\mathrm{j} ; \gamma_{\mathrm{i}}=$ effect of day or week i; $\alpha \gamma_{\mathrm{ij}}=$ effect of interaction of breed $\mathrm{j}$ and day or wk l; and $\varepsilon_{\mathrm{ijklm}}=$ random error associated with cow $\mathrm{k}$ in block $\mathrm{i}$ and breed $\mathrm{j}$ at day or wk $\mathrm{l}$.

Daily DMI for individual cows were fitted to the exponential equation (Hayirli et al., 2003) using the NLIN procedure of SAS (SAS Institute, 1999). The equation was: $\mathrm{DMI}=\mathrm{a}+\mathrm{be}^{(\mathrm{ct})}$, where $\mathrm{a}=$ asymptotic intercept at time $-\infty, b=$ potential for decrease in intake or magnitude of intake depression from the asymptotic intercept until parturition, $\mathrm{c}=$ rate constant influencing the shape of the curve, and $t=$ day relative to parturition $(t=-21,-20, \ldots-1)$. Equation parameters were analyzed using the MIXED procedure of SAS (SAS Institute, 1999). The model was:

$$
\mathrm{Y}_{\mathrm{ij}}=\mu+\rho_{\mathrm{i}}+\alpha_{\mathrm{j}}+\varepsilon_{\mathrm{ij}}
$$

where $\mathrm{Y}_{\mathrm{ij}}=$ the dependent variable in block $\mathrm{i}$ and breed $\mathrm{j} ; \mu=$ common mean; $\rho_{\mathrm{i}}=$ effect of block $\mathrm{i}(\mathrm{i}=1,2, \ldots 14)$; 
$\alpha_{\mathrm{j}}=$ effect of breed $\mathrm{j}\left(\mathrm{j}=\right.$ Holstein or Jersey); and $\varepsilon_{\mathrm{ij}}=$ random error associated with block $i$ and breed $j$.

\section{RESULTS AND DISCUSSION}

Because predicted and actual calving dates differed, plasma samples taken before calving were grouped as d $21 \pm 2.7$ prepartum, d $14 \pm 1.7$ prepartum, d $11 \pm 1.0$ prepartum, d $9 \pm 0.9$ prepartum, $d \pm 0.7$ prepartum, d $5 \pm 1.2$ prepartum, $d 3$ prepartum $(3 \pm 1.0$ and $n=$ 14 for Holsteins and $3 \pm 0.9$ and $n=14$ for Jerseys), and $d 1$ prepartum $(1 \pm 0$ and $n=13$ for Holsteins and $12 \pm 0.4$ and $n=13$ for Jerseys). Samples from 2 Jersey cows were not collected at $\mathrm{d} 1$ postpartum due to complications resulting from milk fever.

Body weight was greater $(P<0.001)$ for Holsteins compared with Jerseys; 837 and $569 \pm 20 \mathrm{~kg}$, respectively. Body weight increased linearly $(P<0.01)$ during the last $3 \mathrm{wk}$ of gestation at a rate of $6 \mathrm{~kg} / \mathrm{wk}$. Body condition score did not differ between breeds (3.54 and $3.68 \pm 0.11$ for Holsteins and Jerseys, respectively) and did not differ over the experimental period.

As expected, DMI decreased for both Holsteins and Jerseys as parturition approached. The interaction of breed $\times$ day prepartum was significant for DMI expressed in kilograms $(P<0.001)$ and as a percentage of BW $(P<0.05)$ as shown in Figure 1 . Dry matter intake decreased $35 \%$ for Holsteins and $17 \%$ for Jerseys over the last 3 wk of gestation, with most of the decline occurring the last week of gestation for both breeds. Using a large database, Hayirli et al. (2003) reported a $32 \%$ decline in DMI for multiparous Holstein cows during the prefresh transition period. However, a difference in prepartum DMI depression between Holsteins and Jerseys has not been reported.

To determine if extent and rate of DMI decline differed between breeds, daily DMI data were fitted to exponential models and are summarized in Table 1. For models predicting DMI expressed as kilograms per day, coefficients "a" and "b" were different for Holsteins and Jerseys; whereas coefficient "c" was similar. The asymptotic intercept or coefficient "a" was greater $(P<$ 0.001) for Holsteins, which is expected when DMI is expressed in kilograms. Coefficient "b" or magnitude of intake depression from the asymptotic intercept until parturition was less $(P<0.01)$ for Jerseys, which indicates that the magnitude of intake depression in late gestation is less for Jerseys compared with Holsteins. When DMI was expressed as a percentage of BW, coefficient "b" was greater $(P<0.05)$ for Holsteins compared with Jerseys; but coefficients "a" and "c" were not different between breeds.

After adjusting for BW, Hayirli et al. (2003) reported substantial variability in DMI between animals within
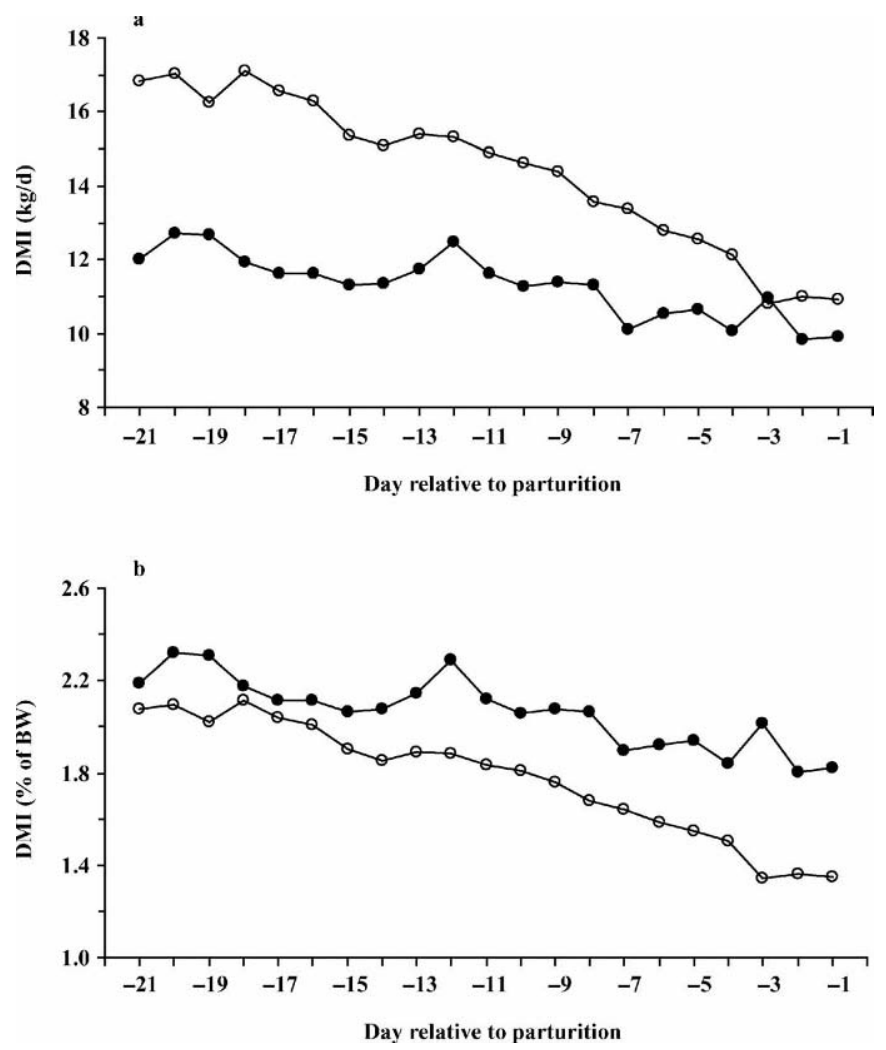

Figure 1. Least squares mean daily DMI expressed as $\mathrm{kg} / \mathrm{d}$ (a) and percentage of BW (b) by day relative to parturition for Holsteins $(\bigcirc)$ and Jerseys $(\bullet)$. Interaction for breed by time was significant at the level of $P<0.001(\mathrm{SE}=0.6, \mathrm{n}=14)$ and $P<0.05(\mathrm{SE}=0.12, \mathrm{n}=$ 14) for DMI expressed as kilograms/day and percentage of BW, respectively.

days. Likewise, in the current experiment daily DMI for individual cows fitted to the common exponential equation resulted in low $R^{2}$. Daily DMI for individual cows were also fitted to a second-order polynomial equation (not reported) with no improvement in $\mathrm{R}^{2}$.

Plasma glucose $(60.5$ vs. $60.7 \pm 0.7 \mathrm{mg} / \mathrm{dL}$ for Holsteins and Jerseys, respectively) and BHBA (6.4 vs. 6.7 $\pm 0.2 \mathrm{mg} / \mathrm{dL}$ for Holsteins and Jerseys, respectively) did not differ between breeds. The effect of day was significant $(P<0.01)$ for both glucose and BHBA (data not shown). Plasma glucose began increasing the day before parturition, peaked the day of parturition, and decreased dramatically the day after parturition. Plasma BHBA remained relatively unchanged until the day after parturition, where concentrations increased $30 \%$. These temporal changes in glucose and BHBA are in agreement with the results of Putnam et al. (1999).

The interaction of breed $\times$ day was significant for plasma NEFA $(P<0.01)$. As shown in Figure 2 , plasma NEFA was similar for the two breeds from 21 to $5 \mathrm{~d}$ prepartum; thereafter, NEFA was greater for Holsteins 
Table 1. Parameter estimates for the exponential model ${ }^{1}$ of daily DMI expressed as $\mathrm{kg} / \mathrm{d}$ and percentage of BW

\begin{tabular}{|c|c|c|c|c|c|c|c|c|}
\hline \multirow[b]{2}{*}{ Parameter } & \multicolumn{3}{|c|}{ DMI, kg/d } & \multirow[b]{2}{*}{$P=$} & \multicolumn{3}{|c|}{ DMI, \% of BW } & \multirow[b]{2}{*}{$P=$} \\
\hline & Holstein & Jersey & SEM & & Holstein & Jersey & SEM & \\
\hline $\mathrm{a}$ & 18.4 & 13.4 & 0.7 & $<0.001$ & 2.29 & 2.47 & 0.18 & 0.84 \\
\hline$-b$ & 9.2 & 3.6 & 0.9 & 0.003 & 1.14 & 0.64 & 0.15 & 0.04 \\
\hline c & 0.107 & 0.110 & 0.026 & 0.93 & 0.107 & 0.110 & 0.026 & 0.93 \\
\hline $\mathrm{R}^{2}$ & 0.27 & 0.07 & & & 0.26 & 0.07 & & \\
\hline
\end{tabular}

${ }^{1} \mathrm{DMI}=\mathrm{a}+\mathrm{be}^{(\mathrm{ct})}$, where $\mathrm{a}=$ asymptotic intercept at time $-\infty, \mathrm{b}=$ intake depression from the asymptotic intercept until parturition, $c=$ rate constant influencing the shape of the curve, and $t=$ day relative to parturition $(\mathrm{t}=-21,-20, \ldots-1)$.

from d 3 prepartum to $1 \mathrm{~d}$ postpartum (775 vs. $521 \mu \mathrm{Eq} /$ $\mathrm{L}$ for $3 \mathrm{~d}$ prepartum to $1 \mathrm{~d}$ postpartum; SEM = 67). The exponential increase in plasma NEFA for Holsteins began on $\mathrm{d} 7$ prepartum and peaked at parturition, which is in agreement with previous reports (VazquezAñon et al., 1994; Putnam et al., 1999). Although plasma NEFA for Jersey cows did increase 2-fold from 21 to $3 \mathrm{~d}$ prepartum, the precipitous rise did not occur until the day before parturition. Rastani et al. (2001) reported that Holsteins had greater NEFA concentration 1 wk postpartum compared with Jerseys; however, prepartum NEFA did not differ for samples collected at 4 and 2 wk prepartum. McNamara and Hillers (1986a) reported an increase in hormone-sensitive lipase, the key enzyme responsible for release of NEFA from adipose tissue, activity of Holstein dairy cows from late gestation to early lactation with the initial adaptation period of increased adipose tissue lipolysis between 20 to $15 \mathrm{~d}$ prepartum (McNamara and Hillers, 1986b). Although not measured in this experiment, breed differences for plasma NEFA may be due in part to pretranslational or posttranslational mechanisms regulating hormone-sensitive lipase activity. Differences in NEFA

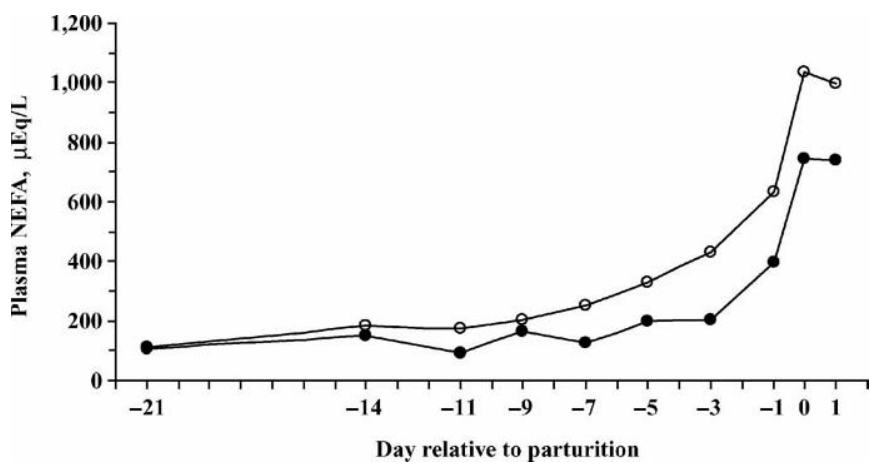

Figure 2. Least squares mean plasma NEFA by day relative to parturition for Holsteins $(\bigcirc)$ and Jerseys $(\bullet)$. Interaction for breed by time was significant at the level of $P<0.01(\mathrm{SE}=67, \mathrm{n}=14)$. Nonesterified fatty acids were greater for Holsteins from $3 \mathrm{~d}$ prepartum to $1 \mathrm{~d}$ postpartum relative to Jerseys. were not due to BCS, because BCS was similar between breeds.

Grummer (1995) reported that feed intake at $1 \mathrm{~d}$ prepartum was negatively correlated to plasma NEFA. In the current experiment, DMI at $1 \mathrm{~d}$ prepartum was negatively correlated to plasma NEFA for Holsteins $(\mathrm{r}=$ $-0.58 ; P<0.05)$ and tended to be negatively correlated for Jerseys $(\mathrm{r}=-0.51 ; P<0.10)$. Grummer et al. (2004) proposed that the change in DMI over the last $3 \mathrm{wk}$ of gestation might be more important than quantity of DM consumed. The decline in DMI, expressed as percentage decrease, for Holsteins from 21 to $1 \mathrm{~d}$ prepartum was positively correlated to plasma NEFA ( $\mathrm{r}=0.62 ; P<$ $0.05)$, but not for Jerseys ( $\mathrm{r}=0.31 ; P=0.28)$. These results indicate an association between prepartum DMI depression and plasma NEFA, but do not show a causal relationship. In a review of intake regulation during the transition period, Ingvartsen and Andersen (2000) noted that negative feedback from the oxidation of NEFA in the liver may down-regulate peripartum DMI when adipose tissue mobilization is high.

In early lactation, mobilization of adipose tissue occurs because DMI increases more slowly than does milk yield leading to negative energy balance (NRC, 2001).

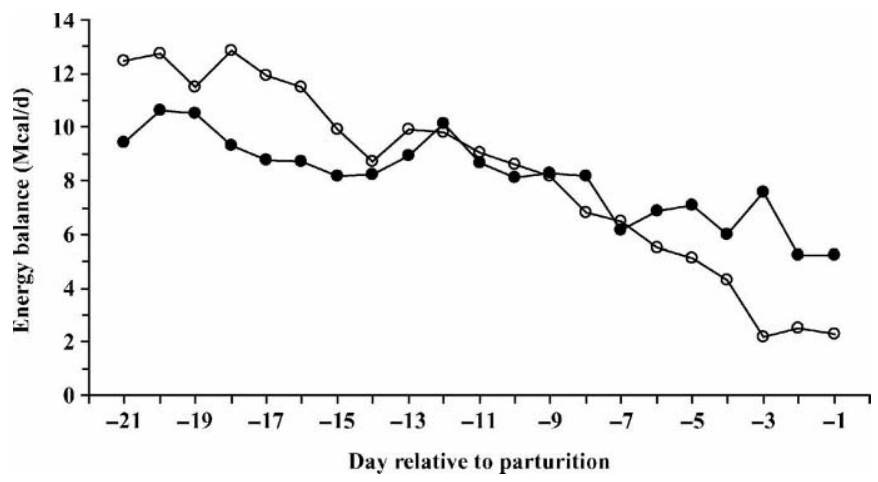

Figure 3. Least squares mean daily energy balance by day relative to parturition for Holsteins $(O)$ and Jerseys $(\bullet)$. Interaction for breed by time was significant at the level of $P<0.01(\mathrm{SE}=1.2, \mathrm{n}=14)$. 
Alternatively, Bareille and Faverdin (1996) proposed that mobilization of adipose tissue during early lactation is the initial event limiting the increase in DMI by a direct metabolic inhibitory effect. When applied to pregnant nonlactating cows, this may aid in explaining the decline in DMI before parturition. In support of this, combined subcutaneous injection of bST and intravenous infusion of a $\beta_{2}$-agonist increased NEFA and decreased DMI in nonlactating cows (Bareille et al., 1997).

The interaction of breed $\times$ day prepartum was significant for energy balance $(P<0.01)$. Energy balance was numerically greater for Holsteins at wk 3 prepartum, similar for breeds at wk 2 prepartum, and tended to be greater $(P<0.10)$ for Jerseys during the last $3 \mathrm{~d}$ of gestation (Figure 3). This interaction was due to the difference in prepartum DMI depression between the two breeds. Rastani et al. (2001) showed that energy balance was greater for Jerseys relative to Holsteins in the first $7 \mathrm{wk}$ of lactation, which they attributed to lower milk energy output for Jerseys. Given the homeorhetic regulation (Bauman and Currie, 1980) that occurs during the transition period, greater plasma NEFA during the prepartum period for Holsteins may be due in part to lower energy balance postpartum. However, when gross efficiency was adjusted for metabolic BW, Jerseys were more efficient than Holsteins during the first 17 wk of lactation (Rastani et al., 2001).

\section{CONCLUSIONS}

Results of this study demonstrate that changes in voluntary DMI and plasma NEFA concentration differ between Holstein and Jersey cows. The magnitude of depression in prepartum DMI as parturition approached was less for Jerseys compared with Holsteins, whereas the elevation in plasma NEFA was greater for Holsteins compared with Jerseys. However, the current study does not identify if the decline in prepartum DMI leads to an increase in NEFA or vice versa. Further research is needed to determine if there is a causal relationship.

\section{REFERENCES}

AOAC. 1997. Official Methods of Analysis. 16th ed. Association of Official Analytical Chemists International, Gaithersburg, MD.
Bareille, N., and P. Faverdin. 1996. Lipid metabolism and intake behavior of dairy cows: Effects of intravenous lipid and $\beta$-adrenergic supplementation. J. Dairy Sci. 79:1209-1220.

Bareille, N., P. Faverdin, and M. Hay. 1997. Modification of feed intake response to a beta 2 -agonist by bovine somatotropin in lactating or dry dairy cows. J. Dairy Sci. 80:52-66.

Bauman, D. E., and W. B. Currie. 1980. Partitioning of nutrients during pregnancy and lactation: A review of mechanisms involving homeostasis and homeorhesis. J. Dairy Sci. 63:1514-1529.

Grummer, R. R. 1995. Impact of changes in organic nutrient metabolism on feeding the transition dairy cow. J. Anim. Sci. 73:2820-2833.

Grummer, R. R., D. G. Mashek, and A. Hayirli. 2004. Dry matter intake and energy balance in the transition period. Vet. Clin. North Am. Food Anim. Pract. 20:447-470.

Hayirli, A., R. R. Grummer, E. V. Nordheim, and P. M. Crump. 2002. Animal and dietary factors affecting feed intake during the prefresh transition period in Holsteins. J. Dairy Sci. 85:34303443.

Hayirli, A., R. R. Grummer, E. V. Nordheim, and P. M. Crump. 2003. Models for predicting dry matter intake of Holsteins during the prefresh transition period J. Dairy Sci. 86:1771-1779.

Ingvartsen, K. L., and J. B. Andersen. 2000. Integration of metabolism and intake regulation: A review focusing on periparturient animals. J. Dairy Sci. 83:1573-1597.

Johnson, M. J., and J. P. Peters. 1993. Technical note: An improved method to quantify nonesterified fatty acids in bovine plasma. J. Anim. Sci. 71:753-756.

Littell, C. R., G. A. Milliken, W. W. Stroup, and F. D. Wolfinger. 1996. SAS System for Mixed Models. SAS Inst., Inc., Cary, NC.

McNamara, J. P., and J. K. Hillers. 1986a. Regulation of bovine adipose tissue metabolism during lactation 2. Lipolysis response to milk production and energy intake. J. Dairy Sci. 69:3042-3050.

McNamara, J. P., and J. K. Hillers. 1986b. Adaptations in lipid metabolism of bovine adipose tissue in lactogenesis and lactation. J. Lipid Res. 27:150-157.

National Research Council. 2001. Nutrient Requirements of Dairy Cattle. 7th rev. ed. Natl. Acad. Sci., Washington, DC.

Putnam, D. E., G. A. Varga, and H. M. Dann. 1999. Metabolic and production responses to dietary protein and exogenous somatotropin in late gestation dairy cows. J. Dairy Sci. 82:982-995.

Raabo, E., and T. C. Terkildsen. 1960. On the enzymatic determination of blood glucose. Scand. J. Clin. Lab. Invest. 12:402-407.

Rastani, R. R., S. M. Andrew, S. A. Zinn, and C. J. Sniffen. 2001. Body composition and estimated tissue energy balance in Jersey and Holstein cows during early lactation. J. Dairy Sci. 84:1201-1209.

SAS Institute. 1999. SAS User's Guide: Statistics, Version 8 ed. SAS Inst., Inc., Cary, NC.

Van Soest, P. J., J. B. Robertson, and B. A. Lewis. 1991. Methods for dietary fiber, neutral detergent fiber, and nonstarch polysaccharides in relation to animal nutrition. J. Dairy Sci. 74:35833597.

Vazquez-Añon, M., S. Bertics, M. Luck, R. R. Grummer, and J. Pinheiro. 1994. Peripartum liver triglyceride and plasma metabolites in dairy cows. J. Dairy Sci. 77:1521-1528.

Wildman, E. E., G. M. Jones, P. E. Wagner, R. L. Bowman, H. F. Troutt, and T. N. Lesch. 1982. Dairy cow body condition scoring and its relationship to selected production characteristics. J. Dairy Sci. 65:495-501.

Williamson, D. H., and J. Mellanby. 1974. D-(-)-3-Hydroxybutyrate. Pages 1836-1840 in Methods of Enzymatic Analysis. Vol. 4. 2nd ed. H. U. Bergmeyer, ed. Acad. Press, London, UK. 